\title{
Increased renal production of C-type natriuretic peptide (CNP) in patients with cirrhosis and functional renal failure
}

\author{
V Gülberg, S Møller, J H Henriksen, A L Gerbes
}

\begin{abstract}
Backgroundlaims-C-type natriuretic peptide (CNP), the third member of the natriuretic peptide family, is considered to be involved in the regulation of vascular tone. Furthermore, the recent demonstration of CNP in human kidney and urine may indicate a role for CNP in fluid and electrolyte homeostasis. Therefore, the aim of the present study was to investigate the possible role of CNP in renal function disturbances in patients with cirrhosis of the liver.
\end{abstract}

Methods-Peripheral venous and urinary concentrations of CNP were determined in samples from 11 healthy controls, 20 cirrhotic patients with normal renal function (creatinine clearance $117(8) \mathrm{ml} / \mathrm{min}$ ), and 20 cirrhotic patients with impaired renal function (creatinine clearance 35 (4) $\mathrm{ml} / \mathrm{min}$ ). In a second protocol, arterial and renal venous plasma concentrations of CNP were determined in 37 patients with cirrhosis of the liver to estimate renal extraction ratios of CNP. A sensitive and specific radioimmunoassay was applied after solid phase extraction of samples.

Results-Plasma CNP was lower in cirrhotic patients with normal and impaired renal function than in controls $(3.0(0.4)$ and $2.7(0.2) \quad v \quad 4.2(0.4) \mathrm{pg} / \mathrm{ml}$, respectively; $p<0.05$; mean (SEM)). In contrast, urinary CNP was higher in patients with impaired renal function compared with those with normal renal function and healthy controls $(47.2(7.4) v 20.8(1.9)$ and 17.0 (3.0) ng CNP/g creatinine, respectively; $p<0.05$ ). Urinary CNP was found to be inversely related to urinary sodium excretion in cirrhotic patients $(r=-0.56$; $\mathrm{p}<0.01)$. No differences were observed between arterial and renal venous concentrations of CNP in cirrhosis (2.4 (0.2) $v 2.4$ (0.2) $\mathrm{pg} / \mathrm{ml}$ ). In cirrhotic patients with hepatorenal syndrome or refractory ascites $(n=5)$, urinary $\mathbf{C N P}$ decreased from 132 (59) to $38(7) \mathrm{ng} / \mathrm{g}$ creatinine $(\mathrm{p}<0.05)$ one week after either ornipressin infusion or insertion of a transjugular intrahepatic portosystemic shunt together with an increase in urinary sodium excretion from 27 (17) to 90 (34) $\mathrm{mmol} / 24$ hours. Conclusions-Increased urinary CNP in cirrhotic patients in the absence of renal arteriovenous concentration gradients suggests enhanced renal CNP production in cirrhosis. Furthermore, an inverse relation between urinary CNP and urinary sodium excretion suggests a role for this peptide in renal sodium handling in patients with cirrhosis.

(Gut 2000;47:852-857)

Keywords: C-type natriuretic peptide; renal function; natriuresis; cirrhosis

Haemodynamic abnormalities are well described in patients with cirrhosis. ${ }^{1}$ Systemic and splanchnic vasodilatation seem to be mediated by an imbalance of vasoconstrictor systems such as renin-aldosterone, the sympathetic nervous system, endothelins, ${ }^{2}$ and circulating vasodilators, and lead to renal vasoconstriction as well as sodium and water retention. ${ }^{3}$ The role of natriuretic peptides is not fully established but it has been proposed that they may act to antagonise sodium retaining humoral systems. ${ }^{4}$

The natriuretic peptide family consists of at least four different peptides with similar amino acid sequences but different sites of synthesis and biological actions. ${ }^{5}$ Atrial natriuretic peptide (ANP) and brain natriuretic peptide (BNP) are cardiac hormones with marked diuretic and natriuretic properties. ${ }^{6}$ Urodilatin shows similar renal effects but in contrast with ANP and BNP is synthesised exclusively by the kidney, suggesting a paracrine role for this peptide. ${ }^{7}$ C-type natriuretic peptide (CNP), initially isolated from central nervous tissues and endothelial cells, ${ }^{8}$ has only moderate natriuretic actions compared with the other natriuretic peptides and acts mainly as a vasodilating agent. ${ }^{9}$ Transcription of CNP has been demonstrated in other tissues such as the liver,${ }^{10}$ heart, and immune organs, ${ }^{11}$ and in different segments of the mammalian kidney. ${ }^{12}$ Furthermore, its presence in human urine ${ }^{13}$ may indicate a role for CNP in fluid and electrolyte homeostasis.

To date, numerous investigations have addressed the role of ANP in disturbances of volume and sodium homeostasis in patients with cirrhosis of the liver ${ }^{14} 15$ and one study has shown increased plasma concentrations of BNP in cirrhosis. ${ }^{16}$ Salo et al demonstrated that urinary excretion of urodilatin is normal in patients with cirrhosis with or without ascites and suggested different regulation of ANP and urodilatin secretion. ${ }^{17}$ Until now, however,

Abbreviations used in this paper: ANP, atrial natriuretic peptide; BNP, brain natriuretic peptide; CNP, C-type natriuretic peptide; HRS, hepatorenal syndrome; TFA, trifluoracetic acid. 
circulating concentrations of CNP in patients with chronic liver disease have not been investigated and there is no information on urinary excretion of CNP in patients with cirrhosis. Therefore, the aim of the present study was to investigate the possible role of CNP in renal function disturbances in patients with cirrhosis of the liver.

\section{Patients and methods}

PATIENTS

Twenty cirrhotic patients (16 males, four females) with normal renal function, defined as creatinine clearance greater than $70 \mathrm{ml} / \mathrm{min}$ (range 73-223; median 110), 20 cirrhotic patients (15 males, five females) with impaired renal function (creatinine clearance 8-63 $\mathrm{ml} / \mathrm{min}$; median 33 ), and 11 age matched controls (six males, five females; creatinine clearance $70-190 \mathrm{ml} / \mathrm{min}$; median 100 ) were investigated. Characterisation of haemodynamic parameters, and renal and liver function of these subjects is shown in table 1. Diagnosis of cirrhosis was based on liver biopsy or clinical, biochemical, and exploratory data. Aetiology of cirrhosis was alcohol abuse in 28 patients, viral hepatitis in eight, primary biliary cirrhosis and sclerosing cholangitis in one patient each, and unknown in the remaining two patients.

None of the control subjects or patients with cirrhosis had evidence of cardiovascular or renal disease. Controls were not receiving any cardiovascular or diuretic medications. Six of 20 patients with normal renal function and 16 of 20 patients with impaired renal function were receiving diuretic drugs (spironolactone and frusemide), the doses of which were held constant at least five days prior to the investigation.

In a second protocol, arterial and renal venous plasma concentrations of CNP were determined in 37 patients with cirrhosis to estimate renal extraction ratios of CNP. Aetiology of cirrhosis was alcohol abuse in 30 patients and viral hepatitis in seven.

The effect of therapeutic interventions on urinary CNP was studied in five patients, three with hepatorenal syndrome (HRS) type 1 and two with refractory ascites and functional renal failure. Patients with HRS were not receiving diuretic drugs during the study; in patients with refractory ascites, medication was held constant during the investigation period.
STUDY PROTOCOLS

Protocol I

A 24 hour urine collection was performed in controls and patients. Aliquots were drawn at the end of the collection period for determination of CNP, sodium, and creatinine. In the morning, at the end of the collection period, blood pressure and heart rate were monitored with the patient in the supine position for at least one hour. At the same time blood was drawn from an antecubital vein for determination of sodium, creatinine, and liver function tests. Blood samples $(10 \mathrm{ml})$ were transferred into prechilled tubes containing $1 \mathrm{mg}$ of EDTA per $\mathrm{ml}$ for determination of CNP and ANP.

\section{Protocol II}

Thirty seven cirrhotic patients were studied in the morning after an overnight fast in the supine position. Catheterisation of the renal vein and femoral artery was performed as described previously. ${ }^{18}$ Briefly, an indwelling catheter was placed into the femoral artery using the Seldinger technique. The renal vein was catheterised with a $7 \mathrm{~F}$ Cournand catheter through the femoral vein under fluoroscopic control. Blood samples were drawn simultaneously from the renal vein and femoral artery after discharging the catheter deadspace. Blood samples were immediately transferred into prechilled tubes containing $1 \mathrm{mg}$ of EDTA per $\mathrm{ml}$ for determination of CNP.

\section{Protocol III}

Changes in urinary CNP and urinary sodium excretion were investigated in five patients with cirrhosis of the liver who underwent therapeutic interventions to improve renal function: three patients with type 1 HRS were investigated before and after one week of ornipressin infusion $(6 \mathrm{IU} / \mathrm{h})$ and two patients were studied before and one week after placement of a transjugular intrahepatic portosystemic shunt for refractory ascites. Interventions were performed as described elsewhere in detail. ${ }^{19}{ }^{20}$

The study protocols were approved by the ethics committees of medical research both in Munich and Copenhagen, and all patients gave informed consent.

\section{LABORATORY ANALYSIS}

For determination of CNP, a sensitive and specific radioimmunoassay (cross reactivity to human ANP and BNP <1\%; Peninsula,

Table 1 Patient characteristics

\begin{tabular}{|c|c|c|c|c|c|c|c|c|c|c|c|c|c|}
\hline \multirow[b]{3}{*}{ Age (y) } & \multirow{3}{*}{$\begin{array}{c}\begin{array}{l}\text { Controls } \\
(n=11)\end{array} \\
45(6)\end{array}$} & \multirow{2}{*}{\multicolumn{2}{|c|}{$\begin{array}{l}\text { Cirrhosis } \\
\text { normal } \\
\text { renal function } \\
(n=20)\end{array}$}} & \multirow{2}{*}{\multicolumn{2}{|c|}{$\begin{array}{l}\text { Cirrhosis } \\
\text { impaired } \\
\text { renal function } \\
(n=20)\end{array}$}} & \multirow{3}{*}{$\begin{array}{l}p \text { Value } \\
\text { NS }\end{array}$} & \multicolumn{6}{|c|}{ Cirrhosis } & \multirow{3}{*}{$\begin{array}{l}p \text { Value } \\
\text { NS }\end{array}$} \\
\hline & & & & & & & \multicolumn{2}{|c|}{$\begin{array}{l}\text { Child A } \\
(n=15)\end{array}$} & \multicolumn{2}{|c|}{$\begin{array}{l}\text { Child B } \\
(n=14)\end{array}$} & \multicolumn{2}{|c|}{$\begin{array}{l}\text { Child C } \\
(n=11)\end{array}$} & \\
\hline & & 52 & (2) & 57 & (2) & & 54 & (2) & 52 & (3) & 58 & (3) & \\
\hline $\mathrm{MAP}(\mathrm{mm} \mathrm{Hg})$ & $100(6)$ & 90 & (2) & 81 & (2) & 0.005 & 92 & (2) & 85 & (3) & 81 & (4) & 0.030 \\
\hline $\operatorname{HR}(1 / \mathrm{min})$ & 77 (3) & 74 & (2) & 79 & (2) & NS & 74 & (2) & 80 & (3) & 79 & (4) & NS \\
\hline $\mathrm{GFR}(\mathrm{ml} / \mathrm{min})$ & $102(15)$ & 117 & (8) & 35 & (4) & 0.001 & 99 & (11) & 87 & (17) & 37 & (6) & 0.004 \\
\hline $\mathrm{UNaV}(\mathrm{mmol} / 24 \mathrm{~h})$ & $197(23)$ & 156 & (15) & 62 & (13) & 0.001 & 133 & (19) & 126 & (21) & 40 & (18) & 0.004 \\
\hline Child-Pugh score (points) & - & & $(0.2)$ & & $(0.5)$ & 0.001 & & $(0.1)$ & & $(0.2)$ & 11.1 & $(0.3)$ & 0.001 \\
\hline Serum albumin $(\mathrm{g} / \mathrm{dl})^{\star}$ & - & & $(0.1)$ & & $(0.2)$ & 0.015 & & $(0.1)$ & & $(0.1)$ & & $(0.2)$ & 0.001 \\
\hline Bilirubin (mg/dl) $†$ & - & & $(0.4)$ & & $(0.4)$ & NS & & $(0.2)$ & & $(0.5)$ & & $(0.8)$ & 0.010 \\
\hline PI $(\%) \ddagger$ & - & 68 & (2) & 69 & (3) & NS & 70 & (3) & 71 & (3) & 60 & (4) & NS \\
\hline
\end{tabular}

MAP, mean arterial pressure; HR, heart rate; GFR, glomerular filtration rate; PI, prothrombin index; UNaV, urinary sodium excretion.

$\star$ Normal range 3.5-5.0; †normal range $<1.0$; łnormal range $70-100$. 


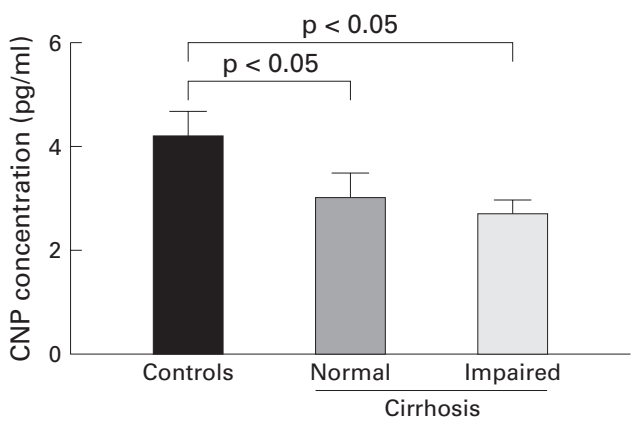

Figure 1 Circulating plasma concentrations of C-type natriuretic peptide (CNP) in control subjects $(n=11)$ and in cirrhotic patients with normal $(n=20)$ or impaired renal function $(n=20)$. Data are mean (SEM).

Merseyside, UK) was applied after solid phase extraction of samples using SepPak C18 cartridges (Waters, Milford, Massachusetts, USA) preconditioned with $1 \mathrm{ml}$ of acetonitrile $60 \%$ in $1 \%$ trifluoracetic acid (TFA) and $9 \mathrm{ml}$ of $1 \%$ TFA. Samples were acidified with an equal volume of $0.1 \%$ TFA and centrifuged for 10 minutes at $6000 \mathrm{~g}$. The supernatant was loaded onto the column which was washed twice with $3 \mathrm{ml}$ of $1 \%$ TFA. The peptides were eluted with $3 \mathrm{ml}$ of acetonitrile $60 \%$ in $1 \%$ TFA and dried in a speed vac concentrator. Extraction recoveries of synthetic CNP added to plasma or urine averaged $85 \%$ and $89 \%$, respectively. Variation coefficients for intraand interassays were $8 \%$ and $15 \%$, respectively. The lower detection limit of this assay was $0.5 \mathrm{pg} /$ tube. Serial dilutions of plasma and urine samples paralleled the standard curve of synthetic CNP, thus demonstrating the validity of the assay. ANP was determined after extraction on XAD2 adsorbent resin (Serva, Heidelberg, Germany) as described previously. ${ }^{20}{ }^{21}$ Briefly, plasma samples were loaded onto a column containing approximately $2 \mathrm{~g}$ of XAD2 adsorbent resin. Columns were washed twice with $10 \mathrm{ml}$ of distilled water, eluted with $4 \mathrm{ml}$ of acetonitrile $55 \%$ and $0.1 \mathrm{M}$ acetic acid $45 \%$, and dried in a speed vac concentrator.

Serum and urinary sodium, and creatinine concentrations were measured using an ion

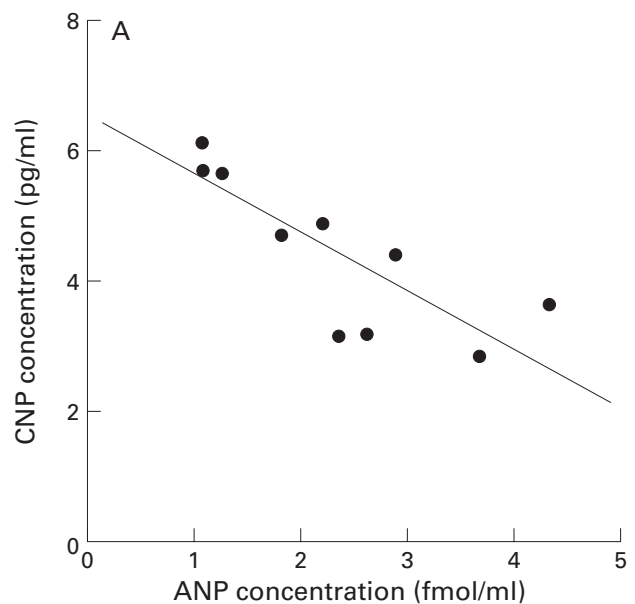

selective probe (Boehringer Mannheim/ Hitachi rack 971, Mannheim, Germany) and the Jaffe reaction, respectively.

STATISTICAL ANALYSIS

Urinary CNP was calculated as (urinary CNP concentration (pg/ml) xurine volume $(\mathrm{ml})$ )/ urinary creatinine $(\mathrm{g})$. Data are presented as mean (SEM). Comparison of mean values between groups was performed using one way ANOVA, and post hoc analysis was calculated using the Student-Newman-Keuls test. Mean values of two groups were compared using the unpaired $t$ test or Mann-Whitney U test, where appropriate. Correlation coefficients (Pearson's $r$ ) were calculated by the least squares method. A p value $<0.05$ was considered statistically significant.

\section{Results}

CIRCULATING CNP CONCENTRATIONS

Plasma CNP was lower in cirrhotic patients with normal $(3.0(0.4) \mathrm{pg} / \mathrm{ml} ; \mathrm{p}<0.05)$ and impaired $(2.7(0.2) \mathrm{pg} / \mathrm{ml} ; \mathrm{p}<0.05)$ renal function than in controls $(4.2(0.4) \mathrm{pg} / \mathrm{ml})$ (fig 1$)$. There were no significant differences in CNP plasma concentrations between patients who did not receive or were receiving diuretic drugs in each group (3.3 (1.8) $\mathrm{pg} / \mathrm{ml} v 3.1(0.4)$ $\mathrm{pg} / \mathrm{ml}$ in patients with normal renal function and $2.7(0.2) \mathrm{pg} / \mathrm{ml} v 2.8(0.3) \mathrm{pg} / \mathrm{ml}$ in patients with impaired renal function, respectively). When circulating CNP levels in different patients were compared according to Child-Pugh class, no statistically significant difference was detected by ANOVA $(2.7(0.2) v$ $3.9(0.7) \mathrm{pg} / \mathrm{ml} v 2.7(0.9) \mathrm{pg} / \mathrm{ml}$ in Child class A, B and C, respectively). An inverse relationship between circulating CNP and ANP was observed in control subjects $(r=-0.80$; $\mathrm{p}=0.005$ ) (fig 2) but not in cirrhotic patients with normal or impaired renal function. Furthermore, there were no correlations between circulating CNP and haemodynamic parameters, liver function tests, or renal function in control subjects. In contrast, in cirrhotic patients with impaired renal function,

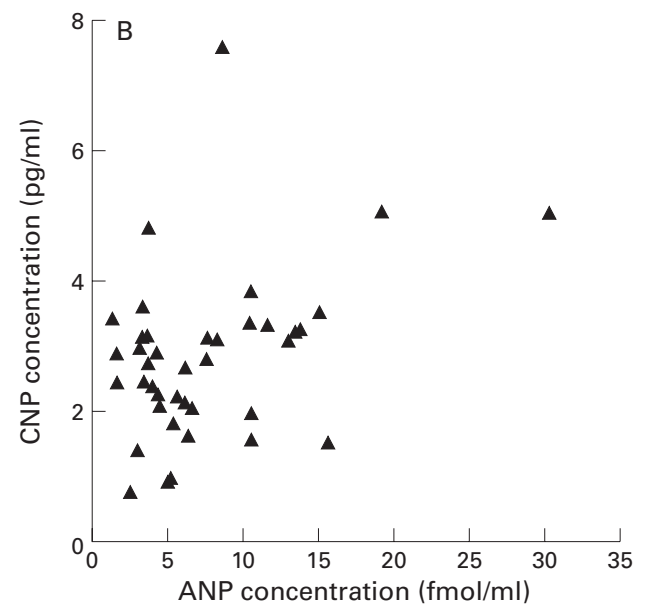

Figure 2 Circulating plasma concentrations of C-type natriuretic peptide (CNP) were inversely correlated with circulating atrial natriuretic peptide $(A N P)$ plasma concentrations in healthy controls $(r=-0.80 ; p=0.005 ; A N P$ plasma concentration only available in 10 subjects; A). No such relationship was observed in cirrhotic patients with normal or impaired renal function (B). 


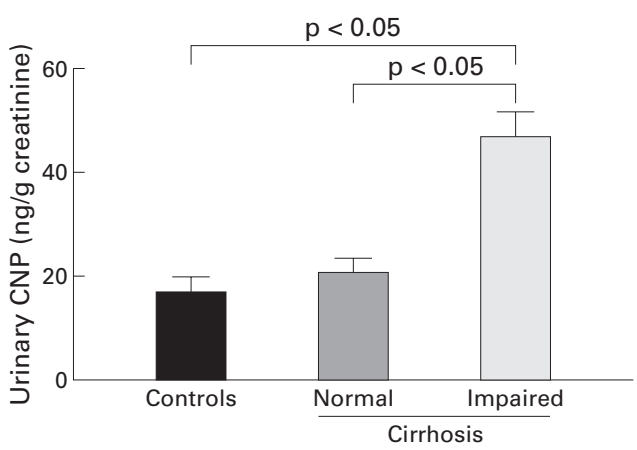

Figure 3 Urinary excretion of C-type natriuretic peptide (CNP) was significantly increased in cirrhotic patients with impaired renal function $(n=20)$ compared with those with normal renal function $(n=20)$ or healthy controls $(n=11)$. Data are mean (SEM).

ANP plasma concentrations were correlated with heart rate $(r=0.529 ; \mathrm{p}=0.017)$ and serum bilirubin $(r=0.532 ; \mathrm{p}=0.016)$, and inversely related to prothrombin index $(r=-0.466$; $\mathrm{p}=0.045)$.

URINARY CNP EXCRETION AND RENAL ARTERIOVENOUS CONCENTRATION GRADIENT Urinary CNP excretion was higher in patients with impaired renal function (47.2 (7.4) ng/g creatinine; $\mathrm{p}<0.05)$ compared with patients with normal renal function (20.8 (1.9) ng/g creatinine) and healthy controls (17.0 (3.0) ng/g creatinine) (fig 3). Urinary CNP excretion did not differ between patients with or without diuretic medication, both in the group with normal renal function (18.8 (1.3) v 21.2 (2.9) $\mathrm{ng} / \mathrm{g}$ creatinine) and in patients with impaired renal function (47.5 (8.0) $v 39.1$ (4.0) $\mathrm{ng} / \mathrm{g}$ creatinine). With respect to Child-Pugh classification, the highest urinary CNP was found in Child class C (51.0 (9.6) ng/g creatinine) which was significantly higher than values in Child class B or A (30.2 (5.9) and 22.7 (15.3) $\mathrm{ng} / \mathrm{g}$ creatinine, respectively; $\mathrm{p}<0.05)$. There was no relationship between urinary CNP and circulating CNP or ANP in controls or in cirrhotic patients with normal or impaired renal function. Urinary CNP, however, was found to be inversely correlated with urinary sodium excretion in cirrhotic patients $(r=-0.56 ; \quad \mathrm{p}<0.01)$ but not in controls $(r=-0.60 ; \mathrm{p}=0.06)$ (fig 4). No differences were observed between arterial and renal venous concentrations of CNP in cirrhotic patients $(2.4(0.2) v 2.4(0.2) \mathrm{pg} / \mathrm{ml})$.

CHANGES IN URINARY CNP EXCRETION AFTER THERAPEUTIC INTERVENTIONS

Urinary CNP in cirrhotic patients with hepatorenal syndrome or refractory ascites decreased from 132 (59) to 38 (7) $\mathrm{ng} / \mathrm{g}$ creatinine $(p<0.05)$ one week after either ornipressin infusion or insertion of a transjugular intrahepatic portosystemic shunt. During the same time an increase in urinary sodium excretion from 27 (17) to 90 (34) $\mathrm{mmol} / 24$ hours was observed (fig 5). Circulating CNP was not significantly influenced by therapeutic interventions (3.4 (0.8) pg/ml before $v 3.0(0.7) \mathrm{pg} / \mathrm{ml}$ one week after intervention).

\section{Discussion}

Ours is the first investigation to assess circulating plasma concentrations of CNP and urinary CNP excretion in patients with cirrhosis of the liver. We found that: (1) concentrations of circulating CNP were decreased; (2) urinary excretion of CNP was increased in cirrhotic patients with impaired renal function but not in patients with normal renal function; (3) there was no relationship between ANP plasma concentrations and urinary CNP excretion or CNP plasma concentration; (4) we did not observe a renal arteriovenous concentration gradient for CNP; (5) an inverse relationship between urinary CNP and urinary sodium excretion was observed in cirrhotic patients; and (6) following interventions which improve renal function in patients with functional renal failure, we found a decrease in urinary CNP while plasma CNP concentrations were not affected.
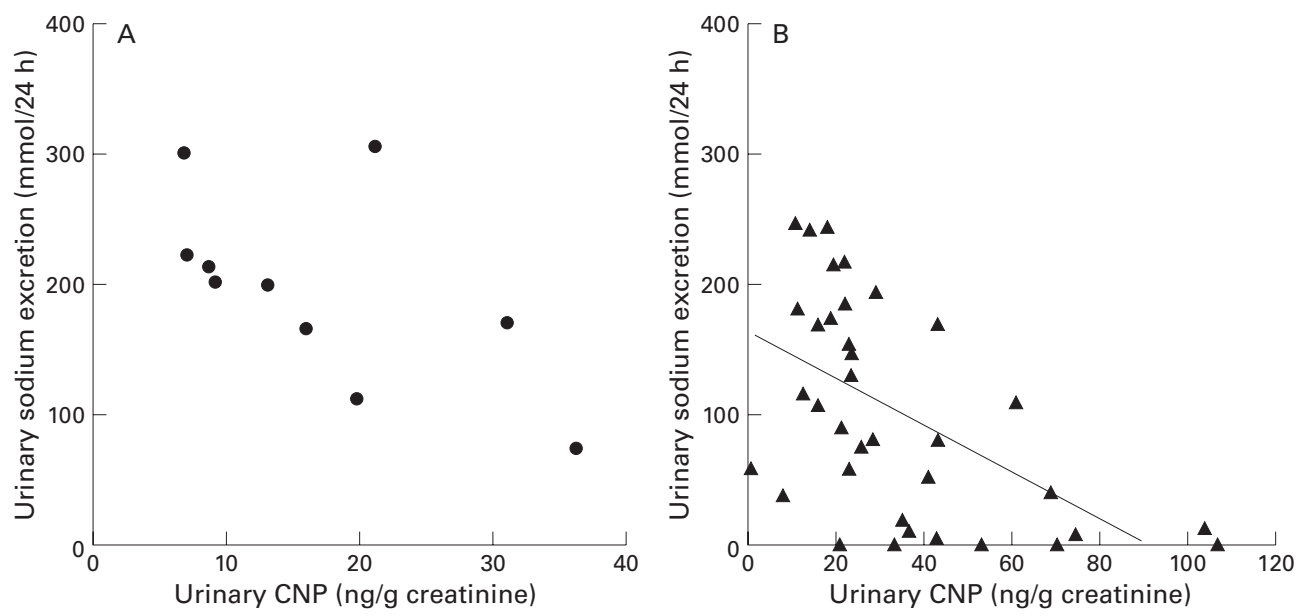

Figure 4 Urinary excretion of C-type natriuretic peptide (CNP) was inversely correlated with urinary sodium excretion in cirrhotic patients $(r=-0.56 ; p<0.01 ; B)$, but not in control subjects $(A)$. 


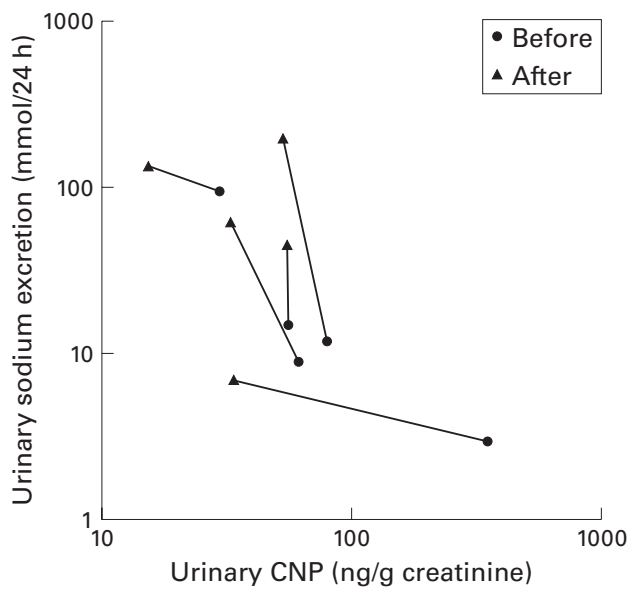

Figure 5 Changes in urinary $C$-type natriuretic peptide (CNP) and natriuresis in five patients following therapeutic interventions. Due to the skewed distribution of the values, both variables are presented on a logarithmic scale.

These findings are of interest because CNP differs considerably from the other natriuretic peptides which have been studied under similar conditions in cirrhotic patients. CNP is the only known endogenous ligand for natriuretic peptide B receptor. ${ }^{4}$ In contrast with ANP and BNP, low dose infusion of CNP does not have an appreciable effect on renal function or systemic haemodynamics in normal humans. $^{22}{ }^{23}$ In rats with experimental cirrhosis and normal sodium excretion, however, pharmacological doses of CNP reduced portal pressure and systemic vascular resistance and increased cardiac output. ${ }^{24}$ These animals showed a blunted natriuretic response to CNP infusion compared with normal rats. In contrast, non-selective blockade of natriuretic receptors did not affect the systemic haemodynamics of rats after carbon tetrachloride induced cirrhosis. ${ }^{25}$

In our patients, circulating concentrations of CNP were decreased compared with control subjects. Although this difference was statistically significant, one might speculate on the biological impact of such a small difference. However, this is the first report of decreased plasma concentrations of a vasodilating substance in cirrhosis of the liver. Moreover, we found an inverse relationship between circulating CNP and ANP in controls but not in cirrhotic patients. This finding suggests regulation of CNP release in cirrhosis which is independent of ANP. A similar situation has been described regarding the natriuretic peptide urodilatin. ${ }^{17}$

To date there has been only one study examining urinary CNP excretion in humans. ${ }^{13}$ In this previous report, CNP excretion in controls was almost comparable with urinary CNP in our healthy subjects. Interestingly, patients with congestive heart failure who share some pathophysiological characteristics of volume regulation with cirrhotic patients showed a similar increase in urinary CNP excretion as our cirrhotic patients with impaired renal function. To further investigate the origin of increased urinary CNP excretion, simultaneous determinations of CNP plasma concentra- tions from a systemic artery and renal vein were performed. Almost identical concentrations in these two vessels exclude major renal extraction of circulating CNP of systemic origin. Instead, we suggest that increased renal production of CNP accounts for the observed increased urinary excretion. Indeed, CNP mRNA and immunohistochemical colocalisation have been described in the proximal convoluted tubule, medullary thick limbs, and inner medullary collecting duct. ${ }^{26}$ Our data indicate that different sites of CNP synthesis or release may be regulated independently. This contention is supported not only by our observation that urinary CNP was increased in patients with decreased CNP plasma levels but also by the results of protocol III in our study which demonstrated unchanged circulating CNP in patients after transjugular intrahepatic portosystemic shunt or ornipressin infusion, while urinary CNP decreased in these patients.

One limitation of the present investigation could be that some patients received diuretic drugs while others did not. As diuretic treatment may induce renal impairment due to volume depletion, this could have affected our results. Therefore, we also analysed our results separately for patients who received and did not receive diuretics in each group and found no significant differences. Thus it seems unlikely that diuretic therapy markedly influenced the results of our study.

It may be speculated that increased urinary CNP may not be influenced by renal function but could be a result of continuous decompensation of liver disease with its well known haemodynamic alterations. ${ }^{3}$ Indeed, urinary CNP was significantly higher in Child-Pugh class $\mathrm{C}$ patients than in class $\mathrm{A}$ or $\mathrm{B}$ patients. This finding, however, was not surprising as there were no patients with Child-Pugh class C cirrhosis and normal renal function in our study population. However, nine of 20 patients with decreased creatinine clearance had Child class A or B cirrhosis. Comparing their CNP plasma levels with those of the Child class C patients did not show a significant difference (3.2 (0.7) $v 2.5(0.4) \mathrm{pg} / \mathrm{ml} ; \mathrm{p}=0.21)$ nor was there a significant difference in urinary CNP excretion (40.1 (9.0) $v 51.0 \quad(9.6) \quad \mathrm{ng} / \mathrm{g}$ creatinine; $\mathrm{p}=0.40)$. Furthermore, the results of our protocol III indicate that improved renal function is paralleled by a decline in urinary CNP after therapeutic interventions which do not affect liver function (ornipressin infu$\operatorname{sion}^{19}{ }^{27}$ ) or are even considered to cause deterioration in hepatic function (transjugular intrahepatic portosystemic shunt $\left.{ }^{20}{ }^{28}\right)$. These findings suggest that urinary CNP excretion is more closely related to renal function itself than to the severity of liver disease.

Our results also support the contention that $\mathrm{CNP}$-paradoxically-acts as an antinatriuretic substance. This has been suggested by Stingo and colleagues ${ }^{29}$ who observed a significant decrease in natriuresis with systemic CNP infusion in the anaesthetised dog. Again, these observations are compatible with our results of an inverse relationship between urinary CNP and natriuresis and the finding that urinary 
CNP decreases after therapeutic interventions that augment natriuresis in patients with cirrhosis.

In conclusion, increased urinary CNP in cirrhotic patients in the absence of renal arteriovenous concentration gradients suggests enhanced renal CNP production in cirrhosis. Inverse relationships between urinary CNP and urinary sodium excretion in cirrhotic patients could indicate a role for this peptide in renal regulation of sodium homeostasis. Therefore, CNP may act as a paracrine mediator of renal function in patients with cirrhosis.

The authors appreciate the valuable technical assistance of I Li $\beta$. This study was supported by the Deutsche Forschungsgemeinschaft (DFG Ge 576/13-1) and a grant from the John and Birthe Meyer Foundation.

1 Schrier RW, Arroyo V, Bernardi M, et al. Peripheral arterial vasodilatation hypothesis: a proposal for the initiation of renal sodium and water retention in cirrhosis. Hepatology 1988;5:1151-7.

2 Moore K, Wendon J, Frazer M, et al. Plasma endothelin immunoreactivity in liver disease and the hepatorenal syndrome. N Engl f Med 1992;327:1774-8.

3 Møller S, Henriksen JH. The systemic circulation in cirrhosis. In: Arroyo V, Gines P, Rodes J, et al, eds. Ascites and renal dysfunction in liver disease. Oxford: Blackwell, 1999: 307-29.

4 Gerbes AL. The role of atrial natriuretic peptide (ANP) in chronic liver disease. Pharmacol Ther 1993;58:381-90.

5 Koller KJ, Goeddel DV. Molecular biology of the natriuretic Koller KJ, Goeddel DV. Molecular biology of the natriuretic peptides and their receptors. Circulation 1992;86:1081-8.
6 Gunning ME, Brenner BM. Natriuretic peptides and the Gunning ME, Brenner BM. Natriuretic peptides and the
kidney: current concepts. Kidney Int 1992;38(suppl.): kidney:

7 Forssmann WG, Richter R, Meyer M. The endocrine heart and natriuretic peptides: histochemistry, cell biology, and functional aspects of the renal urodilatin system. Histochem Cell Biol 1998;110:335-57.

8 Lewicki JA, Portter AA. Physiological studies of the natriuretic petide family. In: Laragh $\mathrm{JH}$, Brenner BM, eds. Hypertension: pathophysiology, diagnosis and management. New York: Raven, 1995:1029-53.

9 Wei CM, Aarhus LL, Miller VM, et al. Action of C-type natriuretic peptide in isolated canine arteries and veins. Am f Physiol 1993;264:H71-3.

10 Vollmar AM, Paumgartner G, Gerbes AL. Differential gene expression of the three natriuretic peptides and natriuretic peptide receptor subtypes in human liver. Gut 1997;40: peptide

11 Vollmar AM, Gerbes AL, Nemer M, et al. Detection of C-type natriuretic peptide (CNP) transcript in the rat heart and immune organs. Endocrinology 1993;132:1872-4.
12 Terada Y, Tomita K, Nonoguchi H, et al. PCR localization of C-type natriuretic peptide and B-type receptor mRNAs in rat nephron segments. Am f Physiol 1994;267:F215-22.
Mattingly MT, Brandt RR, Heublein DM, et al. Presence of C-type natriuretic peptide in human kidney and urine. Kidney Int 1994;46:744-7 (published erratum appeared in Kidney Int 1996;50:1442).

14 Gerbes AL, Arendt RM, Paumgartner G. Atrial natriuretic factor: possible implications in liver disease. $f$ Hepatol 1987;5:123-32.

15 Warner L, Skorecki K, Blendis LM, et al. Atrial natriuretic factor in liver disease. Hepatology 1993;17:500-13.

16 La Villa G, Romanelli RG, Casini VR, et al. Plasma levels of brain natriuretic peptide in patients with cirrhosis. Hepatology 1992;16:156-61.

17 Salo J, Jimenez W, Kuhn M, et al. Urinary excretion of urodilatin in patients with cirrhosis. Hepatology 1996;24: 1428-32.

18 Gerbes AL, Møller S, Gülberg V, et al. Endothelin-1 and -3 plasma concentrations in patients with cirrhosis: role of splanchnic and renal passage and liver function. Hepatology 1995;21:735-9.

19 Gülberg V, Bilzer M, Gerbes AL. Long-term therapy and retreatment of hepatorenal syndrome type 1 with ornipressin and dopamine. Hepatology 1999;30:870-5.

20 Gerbes AL, Gülberg V, Waggershauser T, et al. Renal effects of transjugular intrahepatic portosystemic shunt (TIPS) in cirrhosis of the liver: comparison of patients with ascites and refractory ascites and without ascites. Hepatology 1998; 28:683-8.

21 Gerbes AL, Wernze H, Arendt RM, et al. Atrial natriuretic factor (ANF) and renin-aldosterone in volume regulation of patients with cirrhosis. Hepatology 1989;9:417-22.

22 Hunt PJ, Richards AM, Espiner EA, et al. Bioactivity and metabolism of C-type natriuretic peptide in man. 7 Clin Endocrinol Metab 1994;78:1428-35.

23 Barletta G, Lazzeri C, Vecchiarino S, et al. Low-dose C-type natriuretic peptide does not affect cardiac and renal function in humans. Hypertension 1998;31:802-8.

24 Komeichi H, Moreau R, Cailmail S, et al. Blunted natriuresis and abnormal systemic hemodynamic responses to C-type and brain natriuretic petides in rats with cirrhosis. $\mathcal{f}$ Hepatol 1995;22:319-25.

25 Angeli P, Jimenez W, Arroyo V, et al. Renal effects of natriuretic peptide receptor blockade in cirrhotic rats with ascites. Hepatology 1994;20:948-54.

26 Dean AD, Vehaskari VM, Greenwald JE. Synthesis and localisation of C-type natriuretic peptide in mammalian kidney. Am f Physiol 1994;266:F491-6.

27 Guevara M, Gines P, Fernandez-Esparrach G, et al. Reversibility of hepatorenal syndrome by prolonged administration of ornipressin and plasma volume expansion. Hepatology 1998;27:35-41.

28 Guevara M, Gines P, Bandi JC, et al. Transjugular intrahepatic portosystemic shunt in hepatorenal syndrome: effects on renal function and vasoactive systems. Hepatology 1998;28:416-22.

29 Stingo AJ, Clavell AL, Aarhus LL, et al. Cardiovascular and renal actions of C-type natriuretic peptide. Am $\mathcal{F}$ Physiol 1992;262:H308-12. 